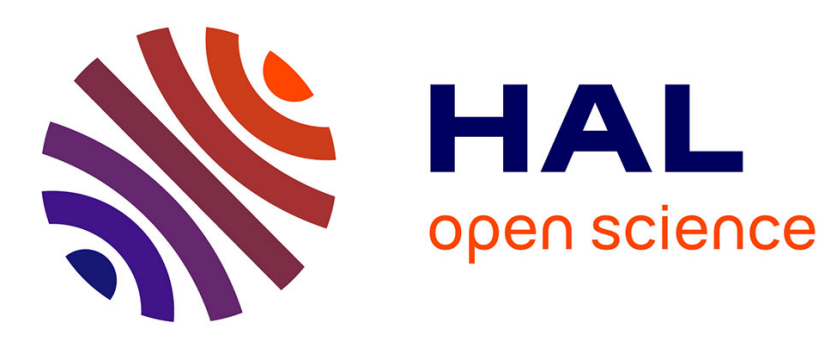

\title{
Double Dividend with Involuntary Unemployment: Efficiency and Intergenerational Equity
}

Mireille Chiroleu-Assouline, Mouez Fodha

\section{To cite this version:}

Mireille Chiroleu-Assouline, Mouez Fodha. Double Dividend with Involuntary Unemployment: Efficiency and Intergenerational Equity. Environmental and Resource Economics, 2005, 31 (4), pp.389403. 10.1007/s10640-005-2040-7 . halshs-00089913

\section{HAL Id: halshs-00089913 https://shs.hal.science/halshs-00089913}

Submitted on 24 Aug 2006

HAL is a multi-disciplinary open access archive for the deposit and dissemination of scientific research documents, whether they are published or not. The documents may come from teaching and research institutions in France or abroad, or from public or private research centers.
L'archive ouverte pluridisciplinaire HAL, est destinée au dépôt et à la diffusion de documents scientifiques de niveau recherche, publiés ou non, émanant des établissements d'enseignement et de recherche français ou étrangers, des laboratoires publics ou privés. 


\title{
Double Dividend with Involuntary Unemployment: Efficiency and Intergenerational Equity
}

\author{
Mireille Chiroleu-Assouline \\ EUREQua - University Paris 1 Panthéon-Sorbonne and ERASME. EUREQua - \\ University Paris 1 Panthéon-Sorbonne, Maison des Sciences Economiques, \\ 106-112 Bd de l'Hôpital, 75647 PARIS Cedex 13. Tel : 331440782 24, Fax : 33 \\ 144078202. Email : assoulin@univ-paris1.fr \\ Mouez Fodha \\ University of Metz, and EUREQua - ERASME. ERASME - Ecole Centrale Paris, \\ Grande Voie des Vignes, F 92295 Chatenay-Malabry Cedex. Tel : 331411314 \\ 51, Fax : 331411316 67. Email : fodham@cti.ecp.fr
}

April 27, 2004

\begin{abstract}
This paper analyzes the double dividend and distributional issues within an overlapping generations models framework with involuntary unemployment. We characterize the necessary conditions for the obtention of a double dividend when the revenue of the environmental tax is recycled by a variation of the labor tax rate. We show that an employment dividend may occur without any efficiency dividend and that the young generation is not always harmed by the fiscal reform, even without any intergenerational transfers. Therefore, three dividends (environmental, efficiency and intergenerational equity) can simultaneously occur.
\end{abstract}

Keywords: Environmental tax, Intergenerational equity, Unemployment, Double dividend

JEL classification: D60, D62, E62, H23, Q28

\section{Introduction}

This paper analyzes the double dividend and equity issues within an overlapping generations models framework with involuntary unemployment. In the absence of altruism, the behavior of private agents accounts for an intergenerational environmental externality. The activity of present generations causes emissions of pollutants which deteriorate the environmental quality, harming the welfare of all future generations. The solution which is usually advocated in order to internalize an environmental externality is the implementation of pigouvian taxes. One of the advantages of such an environmental tax is that it provides a public revenue, which can be recycled. This is the reason why it is often preferred to subsidies or emission quotas.

As governments use the revenues from pollution taxes to decrease other distortionary taxes, environmental taxes improve the quality of

(C) 2004 Kluwer Academic Publishers. Printed in the Netherlands. 
environment and may also lead to an economic benefit: this is the double dividend. These potential gains could be a powerful argument in favor of environmental taxation. The existing literature usually considers many kinds of second dividend: rise in employment, improved efficiency, improved distributional equity (the three kinds of dividend distinguished by Ekins (1995)) or rise in private profits, cut in the cost of public funds, and so on. But Goulder (1995) emphasized that the only convenient criterion refers to economic efficiency, because any other economic benefit is nothing else than a component of global welfare. Since his clarification paper, the double dividend has been unambiguously defined as the combination of an environmental dividend and an efficiency one (by achieving a less distortionary tax system). Nevertheless, an employment dividend can also be defined, which plays in favor of the efficiency dividend without coinciding with it. And moreover, beside these efficiency properties, it can be instructive to also investigate equity issues: when the distributional equity is improved by the recycling of environmental tax revenues, one could as well call this additional benefit a third dividend. The objective of this paper is then to study the existence conditions of a double dividend (according to Goulder's definition), but also the role of the employment dividend and the distributional equity issue. The distributional concern can be viewed between different classes of households (employed and unemployed, poor and rich) or between different generations.

In particular, environmental decisions have an impact on the welfare of both current and future generations, since environmental quality is a public good that different generations share. These intergenerational issues on environmental externalities or on taxation have already been widely studied in the economic literature but the overlapping generation approach, suggested by Solow (1974), (1986), began only to be used for analyzing fiscal problems concerning polluting goods by John and Pecchenino (1994), (1997), John et alii (1995), Howarth and Norgaard (1995), Fisher and van Marrewijk (1998). The main result of all these studies is that environmental taxation implies such a welfare loss for the older generations experiencing the fiscal reform that its implementation can not be wished because the generation which would decide it would also bear the heaviest burden. This result originates in the fact that balanced environmental fiscal reforms have generally not been considered.

The present paper integrates both the efficiency and intergenerational distributional aspects of environmental taxes. By using an overlapping generations model, under the assumption of involuntary unemployment, we examine whether a revenue-neutral increase in the 
pollution tax compensated by a change of the labor tax can yield a double dividend. This general framework can be related to those of Bovenberg and Heijdra (1998), Chiroleu-Assouline and Fodha (2002) and Bovenberg and van der Ploeg (1996) but differs from them in several ways. Bovenberg and Heijdra (1998) do not explicitly address the double dividend issue but investigate whether a higher pollution tax can be Pareto welfare improving by benefiting all generations. In their paper, pollution is due to capital utilization while we assume that the fiscal base of the environmental tax is consumption (which causes pollution) rather than capital; their paper focus mainly on optimal capital taxation which allows them to pay little attention to the employment issue.

The introduction of involuntary unemployment is the main difference between the present paper and Chiroleu-Assouline and Fodha (2002) who show that, even in full-employment, an efficiency dividend is likely to occur, by contrast with the first studies on this issue (Bovenberg and de Moiij 1994). This result depends heavily on the capital intensity of the initial steady state equilibrium relative to the golden rule and on the value of the intertemporal substitution elasticity. But we will show here that the existence of unemployment adds another way for obtaining a double dividend. When the intertemporal substitution elasticity is equal or greater than unity, Chiroleu-Assouline and Fodha (2002) established that no double dividend could occur under full employment assumption, while we will show that such a double dividend can appear when there is initially involuntary unemployment. Moreover their paper addressed an optimality issue while the present one explicitly focuses on second-rank concerns. Lastly, we assume that involuntary unemployment is caused by an exogenous minimum wage rate, like Bovenberg and van der Ploeg (1996) (who do not consider more than one generation). But this is almost the only common point between their work and ours, since they essentially focus on optimal taxation issues and study a very peculiar concept of double dividend which does not correspond to Goulder's definition.

In the second section, we present our model, which relies on standard assumptions of the overlapping generations framework (Diamond 1965). This economy consists of two periods lived individuals working and consuming when young and consuming and being affected by the quality of the environment only when being old. The government is financing its spending (public investment and unemployment benefits) with a labor tax and a pollution tax. We characterize, in the third section, the specification of the fiscal reform when the revenue of the pollution tax is recycled by a variation of the rate of social contri- 
butions instead of by lump-sum transfer. The fourth section focuses on the necessary conditions for the obtention of a double dividend. We show finally that, under some conditions about the variations of the unemployment rate and of the interest rate, an inter-generations distributional dividend can also be obtained.

\section{The model}

By assumption, population size remains constant: $N$ individuals are born in each period $t$. Each individual supplies one unit of labor when she is young and earns a fixed real wage $\bar{w}_{t}$ if she works or a fixed unemployment benefit $b_{t}$ if she is unemployed. Let $E\left({ }_{t}\right)$ be the expected life-cycle income and $u_{t}$ the probability ${ }^{1}$ to be unemployed at time $t$. She divides her income between first-period consumption $c_{t}^{y}$ and saving $s_{t}$; in the second period the individual consumes her saving and the interest she earns. The welfare of an individual born at $t$ is measured with the intertemporal utility function:

$$
U\left(c_{t}^{y}, c_{t+1}^{o}, \Pi_{t+1}\right)=(1-\beta) \ln c_{t}^{y}+\beta\left(\ln c_{t+1}^{o}-\gamma \ln \Pi_{t+1}\right)
$$

with $c_{t+1}^{o}$ denoting her consumption when old and $\Pi_{t+1}$ the level of pollution at $t+1$. The intertemporal discount rate is $\beta /(1-\beta)$ (with $0<\beta<1$ ) and $\gamma$ is the weight of the pollution externality in the welfare evaluation $(\gamma>0)$.

The assumption that pollution only affects the older' welfare is the extreme case of any situation in which the older would be assumed to be more sensitive than the younger to the degradation of the environmental quality ${ }^{2}$ because of their wealth state but also because the satisfaction supplied by their leisure depends upon the environmental quality).

The real interest rate is $r_{t+1}$. The pollution tax rate is $\tau_{t}^{e}$ (the pollution is assumed to be due to consumption, with $a$ the emission rate of pollutants - see below). For each period, the household's budget constraints can be written as follows:

$$
\left\{\begin{array}{l}
E(t)=\bar{w}_{t}\left(1-u_{t}\right)+u_{t} b_{t}=\left(1+a \tau_{t}^{e}\right) c_{t}^{y}+s_{t} \\
\left(1+a \tau_{t+1}^{e}\right) c_{t+1}^{o}=\left(1+r_{t+1}\right) s_{t}
\end{array}\right.
$$

The intertemporal budget constraint of the agent born at $t$ is given by:

$$
p_{t}^{y} c_{t}^{y}+p_{t+1}^{o} c_{t+1}^{o}=\bar{w}_{t}\left(1-u_{t}\right)+u_{t} b_{t}
$$

where $p_{t}^{y}=\left(1+a \tau_{t}^{e}\right)$ is the consumption price of the first period and $p_{t+1}^{o}=\left(1+a \tau_{t+1}^{e}\right) /\left(1+r_{t+1}\right)$ the discounted price of second period. 
The household's problem is to choose her consumption path to maximize her lifetime utility subject to the intertemporal budget constraint. The first order conditions yield:

$$
\frac{\frac{\partial U(.)}{\partial c_{t}^{y}}}{\frac{\partial U(.)}{\partial c_{t+1}^{o}}}=\frac{1-\beta}{\beta} \frac{c_{t+1}^{o}}{c_{t}^{y}}=\frac{p_{t}^{y}}{p_{t+1}^{o}}=\frac{\left(1+a \tau_{t}^{e}\right)\left(1+r_{t+1}\right)}{\left(1+a \tau_{t+1}^{e}\right)}
$$

This relation determines the optimal consumption and saving path of the representative household ${ }^{3}$ :

$$
\left\{\begin{array}{l}
c_{t}^{y}=c^{y}\left(u_{t}, \tau_{t}^{e}\right)=(1-\beta) \frac{E(t)}{p_{t}^{y}} \\
c_{t+1}^{o}=c^{o}\left(u_{t}, r_{t+1}, \tau_{t+1}^{e}\right)=\beta \frac{E(t)}{p_{t+1}^{o}} \\
s_{t}=s\left(u_{t}\right)=\beta E(t)
\end{array}\right.
$$

Production is described by the usual assumptions: the production sector consists of one competitive representative firm, being characterized by a production function which has constant returns to scale and satisfies the Inada conditions; assume that production function has a Cobb-Douglas specification $F\left(K_{t}, L_{t}\right)=K_{t}^{\alpha} L_{t}^{1-\alpha}$ where $K_{t}$ stands for capital and $L_{t}$ for utilized labor. When $\bar{w}_{t}$ is fixed at a too high level for the labor market to be cleared, there is unemployment: with our assumptions of identical households and exogenous labor supply, the unemployment rate equals $u_{t}$ and $L_{t}=\left(1-u_{t}\right) N$. Output per capita $y_{t}=\frac{Y_{t}}{N}$ is a function of capital per capita $\left(k_{t}=\frac{K_{t}}{N}\right)$, i.e. $y_{t}=f\left(k_{t}\right)=$ $\left(1-u_{t}\right)\left[\frac{k_{t}}{1-u_{t}}\right]^{\alpha}$. The maximization problem of the representative firm is:

$$
\underset{k_{t}}{\operatorname{Max}}\left[f\left(k_{t}\right)-\bar{w}_{t}\left(1+\tau_{t}^{w}\right)\left(1-u_{t}\right)-\left(r_{t}+\delta\right) k_{t}\right]
$$

with $\tau_{t}^{w}$ the rate of labor tax, $\bar{w}_{t}$ the fixed real wage per unit of labor and $\delta$ the depreciation rate of capital.

Since capital market is competitive, capital earns its marginal product:

$$
r_{t}=r\left(k_{t}, u_{t}\right)=f^{\prime}\left(k_{t}\right)-\delta=\alpha\left[\frac{k_{t}}{1-u_{t}}\right]^{\alpha-1}-\delta
$$

As far as labor is concerned, the marginal product will adjust to meet the fixed real wage:

$$
\left(1+\tau_{t}^{w}\right) \bar{w}_{t}=\frac{f\left(k_{t}\right)-k_{t} f^{\prime}\left(k_{t}\right)}{\left(1-u_{t}\right)}=(1-\alpha)\left[\frac{k_{t}}{1-u_{t}}\right]^{\alpha}
$$


Note that fixing the real wage leads to an exogenous real interest rate ${ }^{4}$ :

$$
r_{t}=\alpha\left[\frac{\left(1+\tau_{t}^{w}\right)}{(1-\alpha)} \bar{w}_{t}\right]^{\frac{\alpha-1}{\alpha}}-\delta
$$

We assume that government spending is entirely financed by current taxes. The government's budget constraint is that its purchases $\left(g_{t}\right.$ per capita) must equal, at each period $t$, its tax revenues minus the unemployment benefits. The equilibrium of the government's budget is:

$$
a \tau_{t}^{e}\left(c_{t}^{y}+c_{t}^{o}\right)+\left(1-u_{t}\right) \tau_{t}^{w} \bar{w}_{t}-u_{t} b_{t}=g_{t}
$$

The pollution flow is assumed to be due to the household's consumption (waste production, for example), but the household's welfare is affected by the stock of pollution $\Pi_{t+1}$ during the second-period of her life, whose dynamics is described by the following equation:

$$
\Pi_{t+1}=(1-h) \Pi_{t}+a N\left(c_{t+1}^{y}+c_{t+1}^{o}\right)
$$

where $h$ is the constant rate of natural absorption of pollution ( $h \in$ $[0,1[)$ and $a$ the emission rate of pollutants.

The equilibrium of the output good market can be written as follows:

$$
y_{t}=c_{t}^{y}+c_{t}^{o}+k_{t+1}-(1-\delta) k_{t}+g_{t}
$$

which yields, by substituting the zero-profit condition, the government's budget constraint (7) and the household's budget constraints (1), the following equation:

$$
k_{t+1}=s_{t}
$$

which is similar to the equilibrium condition of the capital market $\left(N s_{t}=K_{t+1}\right)$, meaning that the capital stock in period $t+1$ is the amount saved by young individuals in period $t$.

Equation (6) is one equation in the two unknowns, $k_{t}$ and $u_{t}$, which we can write as $u_{t}\left(k_{t}\right)$, and substitute together with (5) into the optimal consumptions and saving of household: this yields their values at the decentralized equilibrium. The dynamics of the economy is obtained by using the equilibrium of the capital market (10):

$$
k_{t+1}=s\left(u_{t}\left(k_{t}\right)\right)
$$


This equation implicitly presents $k_{t+1}$ as a function of $k_{t}$. The steady state equilibrium is defined by $k_{t+1}=k_{t}=k^{*}$, with $k^{*}$ satisfying the following equation of $k$ :

$$
k=s(u(k))
$$

this leads to:

$$
k^{*}=\beta\left[\bar{w}\left(1-u^{*}\right)+b u^{*}\right]
$$

which, together with equation (6) at steady state, determines the unemployment rate $u^{*}$.

The steady state per capita capital stock is independent of the environmental tax rate $\tau^{e}$ :

$$
\mid \begin{aligned}
& k^{*}=\frac{\beta b}{1+A \beta(b-\bar{w})} \\
& u^{*}=1-A k^{*}=\frac{1-A \beta \bar{w}}{1+A \beta(b-\bar{w})}
\end{aligned}
$$

where $^{5}$ :

$$
A=A\left(\bar{w}, \tau^{w}\right)=\left[\frac{1-\alpha}{\left(1+\tau^{w}\right) \bar{w}}\right]^{\frac{1}{\alpha}}>0
$$

At the steady state equilibrium, the stock of pollution is given by:

$$
\Pi^{*}=\frac{a}{h}\left\{c^{y *}\left(u, \tau^{e}\right)+c^{o *}\left(u, r, \tau^{e}\right)\right\}
$$

The unemployment rate is strictly positive $\left(u^{*}>0\right)$ if and only if the fixed real wage $\bar{w}$ is greater than the full-employment equilibrium real wage $w^{f e}$. Adding that the employment has to be non-negative $\left(u^{*}<1\right)$, one can obtain the following necessary and sufficient existence condition for the steady-state equilibrium:

$$
\left(\frac{1+\tau^{w}}{1-\alpha}\right)^{\frac{\alpha}{1-\alpha}}>\frac{\bar{w}}{\underline{w}^{f e}}>1 \quad \text { with } \quad \underline{w}^{f e}=\beta^{\frac{\alpha}{1-\alpha}}\left(\frac{1-\alpha}{1+\tau^{w}}\right)^{\frac{1}{1-\alpha}}
$$

\section{The specification of the fiscal reform}

We assume an exogenous increase of the pollution tax rate, imposed by the government in order to control pollution. The amount of government's purchases $g_{t}$ is assumed ex post invariant. This increase $d \tau^{e}$ of the pollution tax rate causes a variation of the labor tax rate $d \tau^{w}$. At the steady state equilibrium, the government's budget constraint (7) can be written as follows:

$$
g^{*}=\left(1-u^{*}\right) \tau^{w} \bar{w}-u^{*} b+a \tau^{e}\left(c^{y *}+c^{o *}\right)
$$


The link between $d \tau^{e}$ and $d \tau^{w}$ is obtained through the differentiation of this constraint ( with $d g=d b=0)^{6}$. We will give some details about this differentiation in order to clearly distinguish the different effects of the fiscal reform:

- effect on the labor tax revenue:

$$
d\left(\left(1-u^{*}\right) \tau^{w} \bar{w}\right)=\bar{w}\left[1-u^{*}\left(1+E_{u / \tau^{w}}\right)\right] d \tau^{w}
$$

where $E_{u / \tau^{w}}>0$ is the elasticity of the unemployment rate to the labor tax rate. There are here two opposite effects. An increase of the labor tax rate exerts a direct effect on revenue, real wage remaining unchanged. The second effect is an indirect one: as a consequence of the increase of the labor tax rate, the steady state capital stock decreases $\left(E_{k / \tau^{w}}<0\right)$, hence the unemployment increases and its earnings reduces. The labor tax revenue is thus positively affected (this is the Laffer-efficiency condition $\left.^{7}\right)$ if and only if the rate effect is greater than the base effect $\left(u^{*}\left(1+E_{u / \tau^{w}}\right)<1\right)$.

- effect on unemployment global expenses:

$$
b \frac{d u}{d \tau^{w}}>0
$$

The rise in the labor tax rate increases the total labor cost and thus reduces the labor demand. Therefore the unemployment rate increases and the government's expenses grow.

- effect on the pollution tax revenue paid by the younger individuals:

$$
d\left(a \tau^{e} c^{y}\right)=\left(a c^{y *}+a \tau^{e} \frac{\partial c^{y}}{\partial \tau^{e}}\right) d \tau^{e}+a \tau^{e} \frac{\partial c^{y}}{\partial u} \frac{\partial u}{\partial \tau^{w}} d \tau^{w}
$$

Here different effects are also combined. When consumption remains unchanged, increasing the tax rate raises the tax revenue, but the fiscal reform modifies the fiscal base: the direct effect on the consumption price decreases the first-period consumption $\left(\frac{\partial c^{y}}{\partial \tau^{e}}<0\right)$ while the indirect effect through the labor tax increases it when the labor tax decreases $\left(\frac{\partial c^{y}}{\partial u} \underset{-}{\partial \tau_{+}^{w}}<0\right)$.

- effect on the pollution tax revenue paid by the older individuals:

$$
d\left(a \tau^{e} c^{o}\right)=\left(a c^{o *}+a \tau^{e} \frac{\partial c^{o}}{\partial \tau^{e}}\right) d \tau^{e}+a \tau^{e}\left(\frac{\partial c^{o}}{\partial u} \frac{\partial u}{\partial \tau^{w}}+\frac{\partial c^{o}}{\partial r} \frac{\partial r}{\partial \tau^{w}}\right) d \tau^{w}
$$

Concerning the consumption of the older individuals, the modification of the fiscal base is obtained through the combination of three 
effects: the direct effect on the consumption price decreases the second-period consumption $\left(\frac{\partial c^{o}}{\partial \tau^{e}}<0\right)$, the indirect effect through the unemployment rate is the same as the previous one for the younger individuals $\left(\frac{\partial c^{o}}{\partial u}<0\right.$ and $\left.\frac{\partial u}{\partial \tau^{w}}>0\right)$ and the indirect effect through the interest rate $\left(\frac{\partial r}{\partial \tau^{w}}<0\right.$ and $\left.\frac{\partial c^{o}}{\partial r}>0\right)$ magnifies this effect.

The balanced fiscal reform must then respect the following link between the variations of the pollution tax and of the labor tax:

$$
d \tau^{w}=\Lambda d \tau^{e}
$$

with,

$$
\Lambda=-a \frac{\underbrace{\left[D_{1}\right]}_{(\gtrless 0)}+\underbrace{[N]}_{(<0)}[\underbrace{\left[D_{2}\right]}_{(<0)}+\underbrace{\left[D_{3}\right]}_{3}}{\underbrace{}_{(<0)}}
$$

Let us investigate the sign of $\Lambda$ (noting $E_{x / z}$ the elasticity of $x$ to $z)$ :

- $[N]=c^{y *}\left(\begin{array}{c}1+E_{c^{y} / \tau^{e}}<0 \\ <0\end{array}\right)+c^{o *}\left(\begin{array}{c}1+E_{c^{o} / \tau^{e}} \\ <0\end{array}\right)$ is the effect of the change in environmental tax on its revenue. There are both a value effect (the tax revenue increases with the tax rate, for unchanged consumption) and a fiscal base effect (consumption decreases as the tax rate increases, thus the fiscal base erodes) which work in opposite ways.

- $\left[D_{1}\right]=\bar{w}\left[1-u^{*}\left(\begin{array}{c}1+E_{u / \tau^{w}} \\ >0\end{array}\right)\right]$ is the effect of the change of $\tau^{w}$ on its fiscal revenue. There are again both a value effect (the fiscal revenue increases with the tax rate, for unchanged wage) and a fiscal base effect (the unemployment rate increases as the tax rate increases, thus the fiscal base erodes).

- $\left[D_{2}\right]=-\frac{b}{\tau^{w}} u^{*} E_{u / \tau^{w}}$ is the effect of the change of $\tau^{w}$ (via the total effects on unemployment) on revenues of the unemployed. There is only a fiscal base effect: $\left[D_{2}\right]<0$ (since $b$ is unchanged). 
- $\left[D_{3}\right]=\frac{a \tau^{e}}{\tau^{w}}\left(\begin{array}{cc}c^{y *} & E_{c^{y} / u} E_{u / \tau^{w}} \\ <0 & +0\end{array}+c^{o *}\left[\begin{array}{cc}E_{c^{o} / u} E_{u / \tau^{w}}+E_{c^{o} / r} E_{r / \tau^{w}} \\ <0>0\end{array}\right]\right)$ is the effect of the change of $\tau^{w}$ (via the total effects on the unemployment rate) on the fiscal revenues of the pollution tax levied. When the labor tax rate rises, unemployment increases and thus the consumptions and the fiscal revenues decrease. There is only a value effect: $\left[D_{3}\right]<0$.

The sign of $\Lambda$ is ambiguous: it might have been expected that a cut in labor tax would be in any case allowed by an increase in the pollution tax rate, but it is not the case here, because the budget is assumed to be balanced ex post (during each period). Note that, when the labor tax is Laffer-efficient (and thus $\left[D_{1}\right]$ is positive), the sign of the denominator is undetermined. So, even when both taxes are Lafferefficient, the sign of $\Lambda$ is ambiguous. These results can be summarized as follows $\left(\Lambda=-a \frac{N}{D}\right)$ :

As an illustrative example, we have explicitly calculated $\Lambda$ in our very simple model, under some simplifying assumptions $(\delta=1)$. In that case, we show that the environmental tax is always Laffer-efficient but that the labor tax is Laffer-efficient only if the tax rate is small enough: $\tau^{w}<\frac{\alpha b}{\left(1-u^{*}\right)(\bar{w}-b)+b(1-\alpha)}$. Therefore, even in the simplest case, the sign of $\Lambda$ depends on the parameters of the economy and on the initial labor tax rate.

\section{The welfare effects of the fiscal reform}

One can measure the welfare effects of small fiscal changes by the marginal excess burden. This marginal excess burden corresponds to the additional income that has to be provided to the representative household to keep her utility at its initial level (this is the compensatory income variation, denoted $d R_{c}$ ): it stands for the excess welfare loss of the consumers over the tax revenues collected by the government and can be interpreted as the hidden costs of financing public spending. A positive value for the marginal excess burden indicates a loss in welfare after the fiscal reform.

We study here the welfare effect of the fiscal change for a generation during its life-cycle, once the final steady state equilibrium is reached.

Let us determine the compensatory income variation which, after the balanced fiscal reform $\left(d \tau^{w}=\Lambda d \tau^{e}\right)$, would leave the level of 
life-cycle utility unchanged $(d U=0)$ :

$$
(1-\beta) \frac{d c^{y}}{c^{y}}+\beta \frac{d c^{o}}{c^{o}}-\beta \gamma \frac{d \Pi}{\Pi}=0
$$

We use the first-order conditions of the representative household's program (3) and the definition of the compensatory income variation $d R_{c}$ :

$$
d R_{c}-(\bar{w}-b) d u=c^{y *} d p^{y}+p^{y} d c^{y}+c^{o *} d p^{o}+p^{o} d c^{o}
$$

this leads to:

$$
p^{y} d c^{y}+p^{o} d c^{o}-p^{o} c^{o *} \gamma \frac{d \Pi}{\Pi^{*}}=0
$$

As usual in this literature (Bovenberg and de Mooij 1994), one can distinguish an environmental component $d R_{c}^{e}\left(d R_{c}^{e}=p^{o} c^{o *} \gamma \frac{d \Pi}{\Pi^{*}}\right)$ and a non-environmental one $d R_{c}^{n e}\left(d R_{c}^{n e}=(\bar{w}-b) d u+c^{y *} d p^{y}+c^{o *} d p^{o}\right)$ :

$$
d R_{c}=d R_{c}^{n e}+d R_{c}^{e}
$$

The higher the increase in environmental welfare, the lower the increase in consumption prices and the wage decrease and the smaller will be the compensatory income variation.

\subsection{The EXISTEnCE CONDitions OF the FIRST DIVIDEND (ENVIRONMENTAL DIVIDEND)}

The variation of environmental welfare depends both on the sensitivity of welfare to pollution and on the sensitivity of pollution to the consumption of the two generations. As the environmental compensatory income variation grows with pollution, it is clear that the environmental welfare increases if and only if the pollution stock decreases. Differentiating the expression for the steady-state pollution stock (13) yields:

$$
\frac{h}{a} d \Pi=d c^{y}+d c^{o}
$$

Where the consumption variations are given by the following expressions:

- first-period consumption:

$$
d c^{y}=\Lambda_{c}^{y} d \tau^{e} \quad \text { with } \quad \Lambda_{c}^{y}=\left(\frac{\partial c^{y}}{\partial \tau_{-}^{e}}+\frac{\partial c^{y}}{\partial u} \frac{\partial u}{\partial \tau_{+}^{w}} \Lambda_{?}\right)
$$

If the increase of consumption tax results in an increase in labor $\operatorname{tax}(\Lambda>0)$ the effect concerning the consumption of the younger 
individuals is unambiguously negative (unemployment increases since $\tau^{w}$ increases). At the contrary, in case of a cut in labor tax, consumption will decrease only if the negative effect of the pollution tax is greater than the positive effect allowed by the employment augmentation.

- second-period consumption:

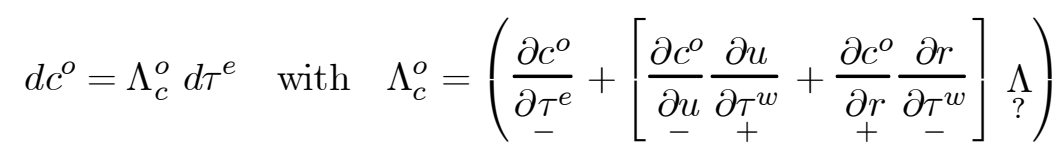

As for the first term $\left(\frac{\partial c^{o}}{\partial u} \frac{\partial u}{\partial \tau^{w}}\right)$, comments are quite similar to the previous ones. The second one features the effect of the tax on the interest rate. If the increase in $\tau^{e}$ requires an increase in $\tau^{w}$, both effects of unemployment increasing and of consumption cost increasing diminish the second-period consumption $c^{o}$. If the increase in $\tau^{e}$ requires a cut in $\tau^{w}$, the effect is unknown because the higher interest rate and the higher employment increase consumption while the higher environmental tax decreases it.

Finally, the variation of pollution is obtained by:

$$
\frac{h}{a} d \Pi=\left(\Lambda_{c}^{y}+\Lambda_{c}^{o}\right) d \tau^{e}
$$

Let us see the precise links between $\Lambda, \Lambda_{c}^{y}$ and $\Lambda_{c}^{o}$ :

- when $\Lambda<0$ :

$$
\left\{\begin{array}{l}
\Lambda_{c}^{y}<0 \text { if and only if } \frac{\partial c^{y}}{\partial u} \frac{\partial u}{\partial \tau^{w}} \Lambda<-\frac{\partial c^{y}}{\partial \tau^{e}} \\
\Lambda_{c}^{o}<0 \text { if and only if }\left(\frac{\partial c^{o}}{\partial u} \frac{\partial u}{\partial \tau^{w}}+\frac{\partial c^{o}}{\partial r} \frac{\partial r}{\partial \tau^{w}}\right) \Lambda<-\frac{\partial c^{o}}{\partial \tau^{e}}
\end{array}\right.
$$

At each period of the household's life, when the rise in pollution tax can be balanced through a reduction of the tax rate on labor, the final effect on consumption will be negative if and only if the price effect is greater than the unemployment effect, that is if the consumption rise due to employment increase is more than compensated by the decrease due to price augmentation.

- when $\Lambda>0$ :

$$
\left\{\begin{array}{l}
\Lambda_{c}^{y}<0 \\
\Lambda_{c}^{o}<0
\end{array}\right.
$$

The environmental dividend will be unambiguously obtained. Note that this will be the case if pollution tax is Laffer-efficient but the labor tax is Laffer-inefficient. 


\subsection{The Existence COnditions of a SeCOnd Dividend (EFFICIENCY DIVIDEND)}

In this framework, the second dividend is obtained when the nonenvironmental compensatory income variation is negative $\left(d R_{c}^{n e}<0\right)$.

- welfare effect through the unemployment rate:

$$
(\bar{w}-b) d u=(\bar{w}-b) \frac{\partial u}{\partial \tau^{w}} \Lambda d \tau^{e}
$$

As $\frac{\partial u}{\partial \tau^{w}}>0$, but as the sign of $\Lambda$ is ambiguous, the effect on employment is undetermined. If the pollution tax rise is balanced by an increase of the tax rate on labor, the employment will decrease, playing against the second dividend (the marginal excess burden would be higher);

- welfare effects through price variations:

$$
\begin{aligned}
& \left\{\begin{array}{l}
d p^{y}=\frac{\partial p^{y}}{\partial \tau^{e}} d \tau^{e}=a d \tau^{e} \\
d p^{o}=\frac{\partial p^{o}}{\partial \tau^{e}} d \tau^{e}+\frac{\partial p^{o}}{\partial r} \frac{\partial r}{\partial \tau^{w}} d \tau^{w}=\left(\frac{\partial p^{o}}{\partial \tau^{e}}+\frac{\partial p^{o}}{\partial r} \frac{\partial r}{\partial \tau^{w}} \Lambda\right) d \tau^{e}
\end{array}\right. \\
& \Leftrightarrow\left\{\begin{array}{l}
d p^{y}=a d \tau^{e} \\
d p^{o}=\frac{1}{1+r}\left(a-p^{o} \frac{\partial r}{\partial \tau^{w}} \Lambda\right) d \tau^{e}
\end{array}\right.
\end{aligned}
$$

The first-period consumption price increases unambiguously but the second-period price may diminish if $\Lambda<0$ (because $\frac{\partial r}{\partial \tau^{w}}<0$ ). In case of an increase of the tax rate on labor $(\Lambda>0)$, both prices are increasing which leads to rise the marginal excess burden of the fiscal reform.

The final effect on non-environmental welfare is measured by the compensatory income variation $d R_{c}^{n e}$ :

$$
\begin{aligned}
d R_{c}^{n e} & =(\bar{w}-b) d u+c^{y *} d p^{y}+c^{o *} d p^{o} \\
& =\left[(\bar{w}-b) \frac{\partial u}{\partial \tau^{w}} \Lambda+a c^{y *}+c^{o *} \frac{1}{1+r}\left(a-p^{o} \frac{\partial r}{\partial \tau^{w}} \Lambda\right)\right] d \tau^{e}
\end{aligned}
$$

Even in the more intuitive case of a decrease of the labor tax $(\Lambda<0)$ which might lead to an environmental dividend, the double dividend can not always be obtained. It depends on the relative magnitude of the effects on the wage, on the environmental welfare and on the fiscal base of the pollution tax.

It is clear that, when $\Lambda>0$, the environmental dividend is obtained 
but never associated with an employment dividend (because $\frac{\partial u}{\partial \tau^{w}}>0$ ) nor an efficiency dividend . By contrast, when $\Lambda<0$, the employment dividend is warranted and, under some conditions, a double dividend according to Goulder's definition (environmental and efficiency) can be obtained.

\subsection{The existence Conditions of a third Dividend (INTERGENERATIONAL EQUITY DIVIDEND)}

Another important question can be asked: is there any possibility for the environmental reform not to imply any non-environmental welfare loss for the generations bearing it? In our static framework of a steady state, we can give a first and partial answer. Let us define the compensatory income variation of the young generation $d R^{y}$ and of the old generation $d R^{o}$ as:

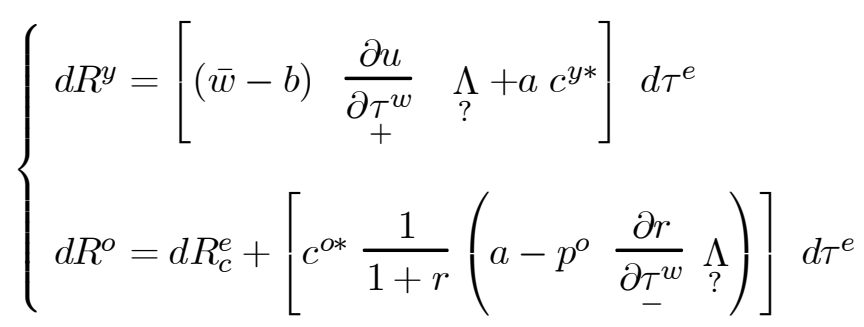

We define our third dividend of intergenerational equity as the possibility for both generations to be better off after the fiscal reform $\left(d R^{y}<0\right.$ and $\left.d R^{o}<0\right)$.

If $\Lambda>0$, the young generation is harmed by the fiscal reform, as well as the old one if the environmental dividend is too small relative to its non-environmental loss of welfare.

If $\Lambda<0$, the welfare gain of the old generation is not warranted: it will exist only if the environmental welfare increases enough to overcompensate the loss incurred because of the increasing pollution tax and the decreasing interest rate. More surprisingly, the compensatory income variation of the young can be negative if the unemployment decreases enough to overcompensate the loss of welfare induced by the taxation of their consumption. Because there is actually an employment dividend, the young generation can also benefit from the environmental fiscal reform: there is a third dividend, without any transfers between generations. To summarize, $\Lambda<0$ is the necessary condition, but not a sufficient one, for the existence of a third dividend. 


\section{Conclusion}

The recent literature on the double dividend issue leads to some clear results (Bosello, Carraro and Galeotti 2001): when the economy is made of one productive sector, using only one productive factor (labor), and one representative consumer, the strong version of the double dividend is rejected. Instead, when there are several productive factors and/or several consumer groups, the double dividend can be obtained but at the expense of equity (Bovenberg and van der Ploeg 1995, Proost and van Regemorter 1995, Bovenberg and Heijdra 1998). This property might question the relevance of the fiscal reform if it harms some generations. Nevertheless, any environmental tax is based on the equity and intergenerational solidarity principle: it aims to give to the future generations the same environmental amenities as to the present generations. But such a fiscal reform will only be acceptable if it improves the global welfare of all generations, the present like the future ones.

We show that the fiscal change does not always harm the welfare of the younger generation and, under certain assumptions about agents' preferences, it is possible to obtain both a double dividend and the respect of intergenerational equity. If the fiscal reform involves a rise in the labor tax rate, the environmental dividend will always be obtained but neither the second dividend (either employment or efficiency) nor the third dividend (equity) can be obtained. By contrast, if the environmental enforcement of the fiscal system yields a decrease of the labor tax rate, the environmental dividend is more likely to occur but the second and third dividends are less likely to occur that the fall in unemployment and the rise in interest rate are greater.

\section{Acknowledgement}

The authors would like to thank two anonymous referees for helpful comments.

\section{Notes}

1. $u_{t}$ can also be viewed as the unemployment duration within the working life of each agent (normalized to 1). Granier and Michel (1994) show that, under perfect expectations, with homothetic utility function, this model is equivalent to any model where $u_{t}$ would stand for the unemployment rate of the aggregate population.

2. Had we assumed that the younger are sensitive, but less sensitive, to the pollution, the results of our model would be qualitatively the same. 
3. Because of the logarithmic utility function, optimal consumption of the young and optimal saving do not depend on the interest rate.

4. It would be equivalent to consider a small open economy with perfect capital mobility, where the interest rate would be imposed by the external world and thus would fix the real wage (including labor tax), causing therefore unemployment.

5. Note that $\frac{d k}{d A}>0, \frac{d A}{d \tau^{w}}<0, \frac{d k}{d \tau^{w}}<0, \frac{d u}{d \tau^{w}}>0$.

6. The unemployment benefits are supposed here to be invariant. The case of their indexation to the consumption price index would also have been interesting to consider (but more difficult to analytically deal with). Our assumption encompasses the case where the unemployment benefit would be determined by a constant replacement rate $\left(b_{t}=b w_{t}\right)$ because here the wage is fixed.

7. A tax is Laffer-efficient if its fiscal revenue grows when the tax rate increases.

\section{References}

Bosello, F., C. Carraro, and M. Galeotti (2001), 'The Double Dividend Issue: Modelling Strategies and Empirical Findings'. Environment and Development Economics 6 (1), 9-45.

Bovenberg, A.L. and B.J. Heidjra (1998), 'Environmental Tax Policy and Intergenerational Distribution'. Journal of Public Economics 67, 1-24.

Bovenberg, A.L. and R.A. de Mooij (1994), 'Environmental Taxes and Labor-Market Distortions'. European Journal of Political Economy 10, 655-683.

Bovenberg, A.L. and F. van der Ploeg (1995), 'Tax Reform, Structural Unemployment and the Environment'. Nota di Lavoro 95.6, FEEM, Milan.

Bovenberg, A.L. and F. van der Ploeg (1996), 'Optimal Taxation, Public Goods and Environmental Policy with Involuntary Unemployment'. Journal of Public Economics 62, 59-83.

Chiroleu-Assouline, M. and M. Fodha (2002), 'Double Dividend Hypothesis, Golden Rule and Welfare Distribution', Working Paper 2002-32, Cahiers de la MSE, University Paris 1.

Diamond, P.A. [1965], 'National Debt in a Neoclassical Model'. American Economic Review 55, 1126-1250.

Ekins, P. (1995), 'On the Dividends from Environmental Taxation', in T. O'Riordan, ed., Ecotaxation. Earthscan Publications.

Fisher, O.N.E. and C. van Marrewijk (1998), 'Pollution and Economic Growth'. Journal of International Trade and Economic Development 67 (1), 55-69.

Goulder, L.H. (1995), "Environmental Taxation and the "Double Dividend": A Reader's Guide'. International Tax and Public Finance, 2, 157-183.

Granier, P., Michel Ph. (1994), 'Les conflits d'intérêt entre les travailleurs qualifiés et les travailleurs non-qualifiés'. Economie et prévision, 115 (4), 125-139. 
Howarth, R.B., Norgaard R.B. (1995), 'Intergenerational Choices under Global Environmental Change', in D. W. Bromley, ed., The Handbook of Environmental Economics. Blackwell, 111-138.

John, A. and R. Pecchenino (1994), 'An Overlapping Generations Model of Growth and the Environment'. The Economic Journal 104, 1393-1410.

John, A. and R. Pecchenino (1997), 'International and Intergenerational Environmental Externalities'. Scandinavian Journal of Economics 99, 371-387.

John, A., R. Pecchenino, D. Schimmelpfennig, and S. Schreft (1995), 'Short-lived Agents and the Long Lived Environment'. Journal of Public Economics 58, 127 141.

Proost, S. and D. van Regemorter (1995), 'The Double Dividend and the Role of Inequality Aversion and Macroeconomic Regimes'. International Tax and Public Finance 2, 207-219.

Solow, R. (1974), 'Intergenerational Equity and Exhaustible Resources'. Review of Economic Studies 41, 29-45.

Solow, R. (1986), 'On the Intergenerational Allocation of Natural Resources'. Scandinavian Journal of Economics 88, 141-149. 